\title{
International and foreign experience of control over the activity of courts (judges)
}

Experiencia internacional y extranjera de control de la actividad de los tribunales (jueces)

Experiência internacional e estrangeira de controle sobre a atividade dos tribunais (juízes)

\section{Oksana Shcherbanyuk ${ }^{1}$ Nadiya Ilchyshyn ${ }^{2}$ \\ Tetiana Stepanova ${ }^{3}$ Alexander Posashkov ${ }^{4}$}

Received: April 25th 2020

Approved: May $31^{\text {th }}, 2020$ Available: June $30^{\text {th }}, 2020$

How to cite this article:

Oksana Shcherbanyuk, Nadiya Ilchyshyn, Tetiana Stepanova \& Alexander Posashkov. International and foreign experience of control over the activity of courts (judges).

DIXI 32, July 2020, 1-11.

DOI: https://doi.org/10.16925/2357-5891.2020.01.08

Artículo de investigación. https://doi.org/10.16925/2357-5891.2020.01.08

1 Doctor of Jurisprudence, Associate Professor, Head of the Department of Procedural Law, Yuriy Fedkovych Chernivtsi National University (Chernivtsi, Ukraine).

E-mail: ablamu4@gmail.com

ORCID: https://orcid.org/0000-0002-1307-2535

2 Candidate of Law (PhD), Judge of the Eights Administrative Court of Appeal (Ukraine).

ORCID: https://orcid.org/0000-0002-0435-6480

3 Doctor of Juridical Sciences, Professor, Professor of the Department of Constitutional Law and Justice, Odesa I.I. Mechnikov National University (Odesa, Ukraine).

ORCID: https://orcid.org/0000-0002-7419-0770

4 Senior Research Fellow, Construction and Road Research Sector, Construction Research Laboratory Kharkiv Research Institute of Forensic Examinations named after Honorable Professor M.S. Bokarius (Kharkiv, Ukraine).

ORCID: https://orcid.org/0000-0002-5701-5874 


\begin{abstract}
This article, based on the analysis of scientific views of scholars, summarizes the foreign experience of control over the activity of courts (judges). After summarizing the experience of Germany, it is stated that the legal mechanism of control over judges in this country is characterized not only by the differentiation of the distribution of supervisory powers at the federal and regional levels, but also by the active involvement of executive and legislative bodies. It is established that the existing foreign experience of control and supervision over the work of judges is quite diverse and can be used by domestic legislators when introducing amendments and additions to current legislation. The most positive experience that can be used in Ukraine to improve the control over the activity of judges includes: 1) The need to improve the procedure for selecting judges; 2) extension of the statute of limitations for committing an offense as a ground for disciplinary liability, in order to reduce the risk of judges avoiding its occurrence; 3 ) introduction of new forms and methods of control in the relevant field; 4) improvement of organizational and legal bases of public involvement in the implementation of control and supervision measures in the area under study.
\end{abstract}

Keywords: Control, courts, foreign experience, judges, legislation, normative legal act.

\title{
Resumen
}

Este artículo, con base en el análisis de opiniones científicas de los académicos, resume la experiencia extranjera de control de la actividad de los tribunales (jueces). Tras resumir la experiencia de Alemania, se afirma que el mecanismo jurídico de control sobre los jueces en este país se caracteriza no solo por la diferenciación de la distribución de las facultades de supervisión a nivel federal y regional, sino también por la participación activa de los órganos ejecutivos y legislativos. Se establece que la experiencia extranjera existente en materia de control y supervisión de la labor de los jueces es muy diversa y puede ser utilizada por los legisladores nacionales al introducir enmiendas y adiciones a la legislación vigente. La experiencia más positiva que puede utilizarse en Ucrania para mejorar el control de la actividad de los jueces incluye: 1) la necesidad de mejorar el procedimiento de selección de los jueces; 2) la ampliación del plazo de prescripción de la comisión de una infracción como motivo de responsabilidad disciplinaria, a fin de reducir el riesgo de que los jueces eviten que se produzca; 3) la introducción de nuevas formas y métodos de control en el campo pertinente; 4) la mejora de las bases organizativas y jurídicas de la participación pública en la aplicación de medidas de control y supervisión en el área objeto de estudio.

Palabras clave: control, tribunales, experiencia extranjera, jueces, legislación, acto normativo legal.

\section{Resumo}

Este artigo, com base na análise de visões científicas de estudiosos, resume a experiência estrangeira de controle sobre a atividade dos tribunais (juízes). Após resumir a experiência da Alemanha, afirma-se que o mecanismo jurídico de controle dos juízes neste país se caracteriza não só pela diferenciação da distribuição dos poderes de fiscalização nos níveis federal e regional, mas também pelo envolvimento ativo do Executivo e órgãos legislativos. Está estabelecido que a experiência estrangeira existente de controle e supervisão sobre o trabalho de juízes é bastante diversa e pode ser usada por legisladores nacionais ao introduzir emendas e adições à legislação em vigor. A experiência mais positiva que pode ser usada na Ucrânia para melhorar o controle sobre a atividade dos juízes inclui: 1) A necessidade de melhorar o procedimento de seleção dos juízes; 2) extensão do prazo de prescrição para a prática de crime como fundamento de responsabilidade disciplinar, de forma a reduzir o risco de os juízes evitarem a sua ocorrência; 3 ) introdução de novas formas e métodos de controle no campo relevante; 4) melhoria das bases organizacionais e jurídicas do envolvimento público na implementação de medidas de controlo e fiscalização na área em estudo.

Palavras-chave: Controle, tribunais, experiência estrangeira, juízes, legislação, ato jurídico normativo. 


\section{INTRODUCTION}

With the adoption of the Law of Ukraine "On Amendments to the Constitution of Ukraine (Regarding Justice)" and with the new version of the Law of Ukraine "On the Judiciary and the Status of Judges" in 2016, a new stage of judicial reform has begun. However, the new version of the said law and the implementation of appropriate changes in the organization of the judiciary did not solve all the problems that existed, and in some areas of the judiciary it even created new ones. In particular, the main ones are: The lack of the necessary level of qualification of judges, starting from the stage of selection of candidates for the position of judges and ending with advanced training of judges; mainly declarative nature of socio-economic, organizational, moral and ethical and other legal guarantees to ensure the service by judges in Ukraine; lack of effective control and supervision over the service of judges in Ukraine, etc. In the context of the latter, it should be emphasized that today there is no systematic analysis and mechanism for using the positive foreign experience of service by judges. We are convinced that the study of foreign experience will allow not only to compare the national legal system with foreign counterparts, but also to determine the existence of truly effective legal norms suitable for implementation (in the short or long-term perspective) in the domestic legal field.

\section{STUDY ANALYSIS AND PROBLEM STATEMENT}

A comprehensive study of the international and foreign experience of control over the activity of courts (judges) is of great theoretical and practical significance. Such scholars as V. A. Kerymov, M. I. Kozyubra, V. O. Kotyuk, V. V. Koshchinets, L. A. Luts, B. V. Malyshev, M. M. Marchenko, M. I. Melnyk, N. M. Onishchenko, I. V. Nazarov, V. T. Nor, N. M. Parkhomeko, A. H. Saidov, A. O. Selivanov, J. P. Shvydenko, D. Yu. Khoroshkovska, S. V. Shevchuk, V. I. Yamkovskyi and others considered some problematic aspects related to the supervision and control over the activities of judges. However, despite the significant scientific achievements on this issue, there are still several problems in this area, the solution of which should be preceded by a study of the most positive foreign experience.

The purpose of the article is to generalize foreign experience of supervision and control over the activities of judges, as well as to determine the possibility of its use in Ukraine. 


\section{RESEARCH RESULTS}

Identifying the problems of the legal mechanism of control over courts and judges in Ukraine helps the introduction of European standards of control over judges in the judicial reform of 2016 (including the principle of quantitative advantage in the personnel of control entities with key functions of appointment and dismissal of judges - judicial authorities, exclusion from the administrative competence of the executive and legislative authorities of the power to dismiss courts), and until the expectations are met, the court continues to be dependent on political and administrative factors. At the same time, several norms that were once criticized by European partners are currently almost the only examples of a positive transformation of the judiciary.

Thus, in paragraph 75 of the conclusion of the Office for Democratic Institutions and Human Rights (OSCE) on the current law "On the Judiciary and the Status of Judges" in Ukraine, it was noted that in accordance with international standards, in order to protect the independence of the judiciary, individual evaluation should be carried out primarily by judges, which will protect the procedure from external, allegedly improper, influence. In Ukraine, judges are evaluated by the High Qualifications Commission of Judges with assistance from the Public Integrity Council. If the powers of the Public Council are beyond the scope of powers of a purely advisory body and even allow the Public Council to significantly influence the evaluation results by, in fact, vetoing a positive assessment of a certain judge by the High Qualifications Commission of Judges, this means that the evaluation procedure is no longer entirely within the competence of the judicial self-government body. Therefore, it is desirable to review these additional powers of the Public Council of Integrity and, ideally, to abandon them'. Instead, practice shows that the active work of the Public Integrity Council is the main factor in clearing the judiciary of dishonest, unprofessional judges. At the same time, members of the judiciary, in fact sabotaging cooperation with public institutions, are quite monolithic in this endeavor - regardless of whether they are elected by the quota of the judiciary or by representatives of other branches of government, third parties.

Turning directly to the analysis of the experience of specific European countries, we must first pay attention to the United Kingdom. The peculiarity of the British judiciary is that it consists of three judicial systems - England and Wales, Scotland and

1 Organization for Security and Co-operation in Europe (OSCE). Conclusion of the OSCE Office for Democratic Institutions and Human Rights No. JUD-UKR/298/2017 [RJU/AT] of 30 June 2017 on the Law of Ukraine "On the Judiciary and the Status of Judges". (2020). [Electronic resource]. Available at: https://hcj.gov.ua/sites/default/files/ no_3534_en.doc 
Northern Ireland. All of them should be united by the recently established Supreme Court of the United Kingdom, which is the highest court and has the power to review some of their decisions on legal issues on appeal ${ }^{2}$. An important preventive measure in England is the selection for the position of a judge. Thus, a candidate for the position of a judge must pass a triple selection. First of all, you must be a member of one of the professional corporations of barristers, solicitors. To be considered a lawyer in the UK, you must pass seven modules, which are the basis of legal knowledge. After that, the student receives a Bachelor's degree in Law. Then you need to take a course in legal practice, after which you can get a qualification of a lawyer or barrister ${ }^{3}$. And only from one of these positions you can apply for the position of a judge.

It should be noted that, traditionally, the basis for supervision and control is a complaint about the work of judges. Control measures in England and Wales are currently being processed by the new Bureau of Judicial Complaints, which is accountable to both the Lord Chief Justice (the highest judicial office in England and Wales) and the Lord Chancellor. The final decision is made by the Lord Chief Justice and the Lord Chancellor. If a judge requests a review, a panel of four people is formed, two of whom are judges and two are jurors (who are elected on a schedule from a panel of 20 people, who in turn are elected by open competition). The Lord Chief Justice and the Lord Chancellor may not impose a harsher punishment than the punishment recommended by the Review Panel. If the senior judge is to be dismissed, then the Lord Chancellor makes a proposal for his dismissal to both Houses of Parliament, with a subsequent referral to the Queen in case of support. In the case of low-level judges, the Lord Chancellor dismisses them personally ${ }^{4}$.

Summarizing the review of the legal mechanism of control over judges in the uK (the system in Scotland and Wales is mainly similar to the analyzed example of England and Wales), we note not only a significant limitation of other branches of government in the implementation of control over judges, but also the possibility of substantial judicial reform, which will reformat the previous millennial traditions of state building and functioning of the court in the direction of modern democratic tendencies.

2 I. V. Nazarov. The judicial system of Great Britain and its reform in connection with the membership in the European Union. PROBLEMS OF LEGALITY: A COLLECTION OF SCIENTIFIC WORKS. Yaroslav Mudryi National Law University. (2011). Pg. 179-187, 180.

3 V. V. Koshchinets \& J. P. Shvedenko. Some aspects of qualification training of judges (from the experience of foreign countries). BULLETIN OF THE STATE JUDICIAL ADMINISTRATION OF UKRAINE 4. 2012. Pg. 59-68, 61-62.

4 Henry Brooke. ENGLISH JUSTICE SYSTEM. LORD SLYNN'S EUROPEAN LAW FOUNDATION. (2014). [Electronic resource]. Available at: https: //slynn-foundation.org/wp-content/ uploads/2014/07/The-English-system-of-justice-Ukrainian-judiciary-seminarsUkrainian-version.pdf 
The next European country we will pay attention to is Germany. A judge in Germany plays a very active role in resolving a dispute. They are empowered to question witnesses, examine evidence, and draw the attention of the parties and their weak and strong arguments to the confirmation or denial of the merits of the claims. The judge also has the right to refer to a potentially possible resolution of the dispute by inviting the parties to reach an agreement through mediation before the trial, or an amicable settlement (Vergleich) throughout the trial period. As a general rule, the trial itself lasts one court session, which is the main one (Haupttermin). According to Judge Dr. Patrick M. Bomeke, the primary task of a judge in Germany is to become an assistant in finding a compromise between the parties. According to him, 1/3 of the cases end with the amicable settlement (Vergleich). This is a decision that consists of three parts, including an agreement on the payment of funds (division of obligations), division of court costs and execution of the agreement. The German judicial system encourages the resolution of disputes by concluding amicable agreements, and in particular the Code of Civil Procedure provides for the return of $2 / 3$ of the amount of court fees in the event of resolution of the case by concluding an amicable agreement ${ }^{5}$.

In real life Germany, the courts play an important role in interpreting legal norms, sources of their origin and development; and in participating in law enforcement and, in fact, in the law-making activities of the state ${ }^{6}$. At the same time, most of the references in court decisions are made to the precedents of the court itself, which makes an appropriate decision, and to the decisions of the Constitutional Court. Moreover, the precedents set by the courts in the application of the law are also binding on lawyers and other persons providing legal assistance, since German law provides for the civil liability of lawyers for damages to a client, in particular if the lawyer has shown incompetence in the knowledge of judicial precedents of higher courts?

Taking into account the importance of the courts, considerable attention is paid to supervision and control over their work in Germany. The federal system of Germany provides for different control procedures, depending on the federal or regional level of the relevant court. The Basic Law of the country (Articles 94-96, 98) enshrines the rules that dictate that members of the Constitutional Federal Court (12 persons) are elected in equal proportions by the Bundesrat (upper house of parliament) and the Bundestag (lower house of parliament). Other federal courts (Supreme, Social,

5 N. Tuzhely. EUROPEAN EXPERIENCE (ON SPECIALIZATION AND DECENTRALization OF THE JUDICIAL SYSTEM IN GERMANY). (2015). [Electronic resource]. Available at: https:// yur-gazeta.com/publications/practice/inshe/evropeyskiy-dosvid.html

6 M. N. Marchenko. Sources of LAW. Prospekt. (2005). Pg. 510.

7 Stanislav V. Shevchuk. JUDICIAL LAW-MAKING: WORLD EXPERIENCE AND PROSPECTS IN UKRAINE. Referat. (2007). Pg. 395-398. 
Administrative, Financial, Labor) are elected by a decision of the Federal Minister of Justice or another sectoral minister approved by the Judicial Selection Commission (consisting of the Ministers of Justice of the federation and the same number of people elected by the Bundestag). If a federal judge violates the requirements of the Constitution or encroaches on the constitutional order of a particular region during the performance of his or her official duties, the Federal Constitutional Court may, by a qualified majority (2/3 of the composition), decide to transfer the guilty person to another position, to retire, or, in the case of intentional wrongful conduct, dismiss ${ }^{8}$.

In terms of administrative impact on the court, German experts note the party political "excessive control" over the appointment of judges to the main courts of the country. According to the political schedules at the land and federal levels, in fact, everything is decided by Germany's ruling Christian Democratic and Christian Social Union (CDU/CSU) and by the Social Democratic Party of Germany (SPD). Each year, the issue of several appointments to five federal judges arises, so the two leading parties usually discuss "staffing packages" in advance ${ }^{9}$. That is, the political feasibility of the appointment, party loyalty is also taken into account in resolving personnel issues.

Concluding the review of the German experience, it should be generalized that the legal mechanism of control over judges in this country is characterized not only by differentiation of the division of supervisory powers at the federal and regional levels, but also by active involvement of executive and legislative bodies. At the same time, the procedure of qualification training, internship, examinations of persons who can apply for judicial positions in the future is of scientific interest.

The experience of the Republic of Poland deserves special attention within the framework of the presented issues, because nowadays this country is one of the most successful and most developed post-communist states. In Poland, as in most democracies, power is exercised on the principles of its division into legislative (parliament), executive (government) and judicial. Judicial power is exercised by free and independent courts (Supreme Court, courts of general jurisdiction, administrative courts, military courts), as well as by tribunals (the Constitutional Tribunal is the equivalent of the Ukrainian Constitutional Court and the State Tribunal). This is stated in the Constitution of the Republic of Poland in the article "The power of courts and tribunals is separate and independent from other authorities"10.

8 Deutscher Bundestag. BASIC LAW FOR THE FEDERAL REPUBLIC OF GERMANY. (2019). [Electronic resource]. Available at: https://www.btg-bestellservice.de/pdf/80201000.pdf/

9 Volker Wagener. HOW ARE GERMAN JUDGES SELECTED: DO THE BEST ALWAYS WIN? (2017). [Electronic resource]. Available at: https://p.dw.com/p/2hJGP/

10 O. V. Kuzmenko, I. D. Pastukh, O. E. Korystin, et al. ADMINISTRATIVE LAW OF FOREIGN COUNTRIES: A COURSE OF LECTURES. Jurinkom Inter. (2014). 
The Polish justice system has been restructured since 2015. As part of the judicial reform, laws were passed to reorganize the Supreme Court and the National Council of Justice. The Minister of Justice has been empowered to appoint and initiate the resignation of Supreme Court judges who have been allowed by law to retire early. The provisions on the retirement age of judges were abolished in 2018. Polish judicial reform was criticized in the European Union. In November 2019, the European Court of Justice in Luxembourg ruled that the Polish law of 2017 on the resignation of judges and prosecutors violates Eu rules, as it may allow the Polish Minister of Justice to dismiss judges arbitrarily"1: "The new proposals of the pro-government party of Poland to reform the country's judicial system are in fact a 'liquidation of the judicial system', and it will lead to the country's exit from the Eu in the future". This is declared in a statement of the Head of the Supreme Court of Poland, Malgorzata Gersdorf, regarding the registration a few days ago, by politicians of the right-wing conservative party Law and Justice (PiS), of the new draft law on the structure of courts and the Supreme Court of the country.

Through the momentum of the third amendment of the 1945 Constitution of the Republic of Indonesia, which was passed in 2001, Indonesia has officially adopted a dualistic judicial review system. Under such system, the authority to conduct judicial review is divided/spread to the two judicial organs, each with its own scope of review; namely, the Supreme Court (Mahkamah Agung) reviews regulations below the level of Law (Undangundang), while the Constitutional Court (Mahkamah Konstitusi) reviews the same against the Constitution (constitutional review).

Seen from the theoretical and practical perspective adhered to by states that adopt the formation of the Constitutional Court (centered judicial review model), the system adopted by Indonesia is uncommon, and moreover it could be considered as an error in designing the judicial review system. This is in view of the fact that in states which have a Constitutional Court, the authority to conduct judicial review is concentrated/centered upon the Constitutional Court. Such division of authority under the two-review regime (legal review and constitutional review), as the one practiced by Indonesia, is not known (except for South Korea) neither in states that use the centralized judicial review model nor in those that use the distribution judicial review model.

Such distribution is bound to disrupt the judicial review itself, as the authority to review is implemented by two different institutions with different review standards. In his research, Hamid Chalid puts forward the proposition to centralize the authority to

11 O. Pavliuk. THE EUROPEAN COMMISSION WILL APPLY TO THE COURT OF JUSTICE OF THE EU THROUGH JUDICIAL REFORM IN POLAND. [Electronic resource]. Available at: https://hromadske.ua/posts/yevrokomisiya-zvernetsya-do-sudu-yes-z-privodu-sudovoyi-reformi- v-polshi 
conduct judicial review in the Constitutional Court, thus putting an end to the practice of dualistic judicial review which has been proven to be problematic, and ensuring that the judicial review system in Indonesia can be reconstructed and placed upon the correct theoretical and practical basis ${ }^{12}$.

\section{CONCLUSIONS}

Concluding the presented research, it should be generalized that the existing foreign experience of control and supervision over the work of judges is quite diverse and can be used by domestic legislators when introducing amendments and additions to current legislation. However, it should not be completely copied. It will be more feasible and effective to adapt the positive aspects of foreign legislation to Ukrainian legal realities.

Therefore, the most positive experience that can be used in Ukraine includes:

a) Improving the procedure for selecting judges. This problem is mainly solved by: High level of initial training of future judges, high qualification requirements for candidates for judges, development of effective mechanisms for checking candidates for judges and selection of candidates for these positions, periodic training of judges, improving their qualifications, etc. In some foreign countries, special attention is paid to the psychological examination of a candidate for the position of a judge;

b) It is necessary to extend the statute of limitations for committing an offense as a basis for disciplinary liability in order to reduce the risk of judges avoiding its occurrence;

c) Introduction of new forms and methods of control in the relevant field;

d) To improve the organizational and legal framework for public involvement into the implementation of control and supervision measures in the research area.

Of course, the elements we have identified are quite diverse, in fact, they detail the specifics of the implementation of existing administrative procedures, forms of control, or offer fundamentally new variations. Accordingly, they can be implemented in the short-, medium- or long-term perspective, including in combination with further

12 Hamid Chalid. Dualism of judicial review in Indonesia: Problems and solutions. INDONESIA LAW REVIEW 3. 2017. Pg. 367-394, 367. 
reform, improvement of the overall legal mechanism for regulating the legal status of courts and judges in Ukraine.

\section{REFERENCES}

Deutscher Bundestag. BASIC LAW FOR THE FEDERAL RePublic of GeRmany. (2019). [Electronic resource]. Available at: https://www.btg-bestellservice.de/pdf/80201000.pdf/

Hamid Chalid. Dualism of judicial review in Indonesia: Problems and solutions. INDONESIA LAW REVIEW 3. 2017. Pg. 367-394.

Henry Brooke. ENGLISH JUSTICESYSTEM. LORD SLYNN'S EUROPEAN LAW FOUNDATION. (2014). [Electronic resource]. Available at: https: //slynn-foundation.org/wp-content/uploads/2014/07/TheEnglish-system-of-justice-Ukrainian-judiciary-seminars-Ukrainian-version.pdf

I. V. Nazarov. The judicial system of Great Britain and its reform in connection with the membership in the European Union. Problems OF LEGALITY: A COLLECTION OF SCIENTIFIC WORKS. Yaroslav Mudryi National Law University. (2011). Pg. 179-187.

M. N. Marchenko. SOURCES OF LAW. Prospekt. (2005).

N. Tuzhely. EUROPEAN EXPERIENCE (ON SPECIALIZATION AND DECENTRALIZATION OF THE JUDICIAL SYSTEM IN GERMANY). (2015). [Electronic resource]. Available at: https://yur-gazeta.com/publications/practice/inshe/evropeyskiy-dosvid.html

Organization for Security and Co-operation in Europe (OSCE). CONCLUSION OF THE OSCE OFFICE FOR DEMOCRATIC InStITUtIONS AND HUMAN RIGHTS NO. JUD-UKR/298/2017 [RJU/AT] OF 30 JUNE 2017 ON THE LAW OF UKRAINE "ON THE JUdiciaRy AND THE STATUS OF JUdGES". (2020). [Electronic resource]. Available at: https://hcj.gov.ua/sites/default/files/no_3534_en.doc

O. Pavliuk. The European Commission WiLl apply to the Court of Justice of the EU through JUDICIAL REFORM IN POLAND. [Electronic resource]. Available at: https://hromadske.ua/posts/ yevrokomisiya-zvernetsya-do-sudu-yes-z-privodu-sudovoyi-reformi- v-polshi

O. V. Kuzmenko, I. D. Pastukh, O. E. Korystin, et al. Administrative LaW OF FOREIGn countRies: A COURSE OF LECTURES. Jurinkom Inter. (2014).

Stanislav V. Shevchuk. JUdicIAL LAW-MAKING: WORLD EXPERIENCE AND PROSPECTS IN UKRAINE. Referat. (2007). 
V. V. Koshchinets \& J. P. Shvedenko. Some aspects of qualification training of judges (from the experience offoreign countries). BULLETIN OF THE STATE JUdICIAL ADMINISTRATION OF UKRAINE 4. 2012. Pg. 59-68.

Volker Wagener. How ARE GERMAN JUdGES SELECTED: Do THE BEST ALWAYS WIN? (2017). [Electronic resource]. Available at: https://p.dw.com/p/2hJGP/ 